\title{
Temporal and spatial variation of soil respiration under mulching in a greenhouse cucumber cultivation
}

\author{
Lan $\mathrm{Mu}^{(1)}$, Lan Fang ${ }^{(1)}$ and YinLi Liang ${ }^{(2)}$ \\ (1)Shaanxi Normal University, Institute for Historical Environment and Socioeconomic Development in Northwest China, Xi'an, Shaanxi, 710062, \\ China. E-mail: fanglan001x@163.com, mulan820706@163.com ${ }^{(2)}$ The Institute of Soil and Water Conservation, Chinese Academy of Sciences, \\ and Ministry of Water Resources, Yangling, Shaanxi 712100, China. E-mail: mulan820706@snnu.edu.cn
}

Abstract - The objective of this work was to determine the temporal and spatial variations of soil respiration (Rs) in a greenhouse, as well as the factors causing them, in a soil covered with different mulching types and cultivated with cucumber (Cucumis sativus). Four mulching treatments were applied to a soil cultivated with cucumber: $\mathrm{CK}$, conventional practice without mulch; FM, plastic film mulch; CM, combined mulch of plastic film with wheat straw; and SM, wheat straw mulch. Rs was measured by a soil respiration chamber connected to a portable infrared gas analyzer, and the differences of Rs between mulchings were evaluated. Rs was significantly lower in the control than in the treatments with mulch. In addition, Rs was higher in the position on the soil near plants $\left(5.4 \mu \mathrm{mol} \mathrm{CO} \mathrm{Cm}^{-2} \mathrm{~s}^{-1}\right)$ than in the positions between plants $\left(4.7 \mu \mathrm{mol} \mathrm{CO} \mathrm{Cm}^{-2} \mathrm{~s}^{-1}\right)$ and rows $\left(3.9 \mu \mathrm{mol} \mathrm{CO}_{2} \mathrm{~m}^{-2} \mathrm{~s}^{-1}\right)$. Soil water content and temperature had an interacted effect on Rs. Cucumber root biomass and root vigor should also be incorporated as predictor variables for Rs in the succession crops, mainly for accurately estimating carbon cycling in agroecosystems in a greenhouse.

Index terms: Cucumis sativus, climate change, soil $\mathrm{CO}_{2}$ emission, soil quality.

\section{Variação temporal e espacial da respiração do solo sob cobertura em cultivo de pepino em estufa}

\begin{abstract}
Resumo - O objetivo deste trabalho foi determinar as variações temporais e espaciais da respiração do solo (Rs) em casa de vegetação, assim como os fatores que as causam, em um solo com diferentes coberturas, cultivado com pepino (Cucumis sativus). Quatro tratamentos de cobertura foram aplicados ao solo cultivado com pepino: $\mathrm{CK}$, prática convencional sem cobertura; $\mathrm{FM}$, cobertura com filme plástico; $\mathrm{CM}$, cobertura com filme plástico e palha de trigo; e SM, cobertura com palha de trigo. A Rs foi medida por meio de uma câmara de respiração de solo, conectada a um analisador de gás infravermelho, e as diferenças de Rs entre as coberturas foram avaliadas. A Rs foi significativamente menor no controle do que nos tratamentos com cobertura. Além disso, a Rs foi mais elevada nas posições de solo próximas das plantas $\left(5,4 \mu \mathrm{mol} \mathrm{CO}_{2} \mathrm{~m}^{-2} \mathrm{~s}^{-1}\right)$ do que nas posições entre plantas $\left(4,7 \mu \mathrm{mol} \mathrm{CO} \mathrm{CO}_{2}^{-2} \mathrm{~s}^{-1}\right)$ e entre linhas $\left(3,9 \mu \mathrm{mol} \mathrm{CO} \mathrm{CO}_{2} \mathrm{~m}^{-2} \mathrm{~s}^{-1}\right)$. O teor de água no solo e a temperatura do solo apresentaram efeito interativo sobre a Rs. A biomassa e o vigor radiculares do pepino devem ser incorporados como variáveis preditoras de Rs nos cultivos em sucessão, principalmente para a estimação acurada do ciclo do carbono em agroecossistemas, em casa de vegetação.
\end{abstract}

Termos para indexação: Cucumis sativus, mudanças climáticas, emissão de $\mathrm{CO}_{2}$ do solo, qualidade do solo.

\section{Introduction}

Climate change is mainly caused by increased concentrations of $\mathrm{CO}_{2}$ in the atmosphere, and soil respiration is the major source of soil carbon dioxide $\left(\mathrm{CO}_{2}\right)$, which is released to the atmosphere, and it has a vital importance in the global carbon budget (Dossou-Yovo et al., 2016). Small changes in the magnitude of soil $\mathrm{CO}_{2}$ emission could have a large effect on the concentration of $\mathrm{CO}_{2}$ in the atmosphere (Schlesinger \& Andrews, 2000). In order to reduce and mitigate the potential negative effects of climate change on ecosystems and human well-being, agronomic measures are needed to reduce $\mathrm{CO}_{2}$ emission worldwide (Qiu et al., 2013). In this respect, estimating the magnitude of soil respiration, and its controlling factors under an integrated crop management programme (ICM), is critical for evaluating the role of ecosystems 
in the context of global warming. Mulching is an agronomic practice commonly used for crop production since the mid-1950s, with various benefits to crop production, through additional agroecosystem services, such as weed and disease control, improved soil quality, and increased nutrient cycling (Campiglia et al., 2011). In a study on sunflower, Agele et al. (2010) showed that plastic film mulching improved soil moisture, increased soil temperature, root and shoot biomass, and leaf area development of the plants. Moreover, Guan et al. (2011) found that mulching had a strong influence on the diurnal and seasonal variation of soil respiration (Rs) in a winter wheat field. $\mathrm{Hu}$ et al. (2016) reported that the straw mulching decreased soil carbon emissions by $16 \%$, in comparison to treatments without mulch. Zhao et al. (2016) stated that the straw mixing could increase soil organic carbon content, and improve the composition of microaggregates better than straw mulching. In recent years, mulching effects on Rs have been studied mainly in open-field conditions; however, little information is available regarding the organic carbon stocks in mulching agroecosystems in a greenhouse.

Cucumber (Cucumis sativus L.) has become a favorite commodity for exportation and local consumption, and it represents one of the most important economic vegetables in Egypt, Iran, China, and many other countries (Rahil \& Qanadillo, 2015). Cucumber fields account for $10 \%$ of vegetable land (about $20 \mathrm{Mha}$ ) and about $50 \%$ of cucumber planted in greenhouse in China. It is well known that microclimates were significantly different for cucumber in greenhouse and open-field conditions, especially under the conditions of mulching performance. Therefore, an understanding of the Rs variation under mulching in greenhouse will be useful for calculating carbon emissions more accurately in China.

The objective of this work was to determine the temporal and spatial variations of soil respiration (Rs) in greenhouse, as well as the factors causing them, in a soil covered with different mulching types and cultivated with cucumber.

\section{Materials and Methods}

The experiments were carried out in an experimental greenhouse at the Institute of Soiland WaterConservation, the Chinese Academy of Science, and Ministry of Water Resources, in Yangling $\left(34^{\circ} 12^{\prime}-34^{\circ} 20^{\prime} \mathrm{N}, 108^{\circ}-108^{\circ} 7^{\prime} \mathrm{E}\right.$, at 560 m altitude), Shaanxi, China, from March to August, in 2012 and 2013. Daily mean air temperatures and air humidity data in a greenhouse, during the study (April to August in 2012 and 2013), are presented in Figure 1. Soil characteristics were the following: soil texture was dark loessial soil (464 $\mathrm{g} \mathrm{kg}^{-1}$ sand, $370 \mathrm{~g} \mathrm{~kg}^{-1}$ silt, and $166 \mathrm{~g} \mathrm{~kg}^{-1}$ clay, on average); soil water holding capacity, $24 \%$ (mass basis); soil bulk density, $1.26 \mathrm{~g} \mathrm{~cm}^{-3}$; organic matter content, $14.66 \mathrm{~g} \mathrm{~kg}^{-1}$; total $\mathrm{N}$ content, $0.82 \mathrm{~g} \mathrm{~kg}$ ${ }^{-1}$; total $\mathrm{P}_{2} \mathrm{O}_{5}$ content, $0.99 \mathrm{~g} \mathrm{~kg}^{-1}$; available $\mathrm{N}\left(1 \mathrm{~mol} \mathrm{~L}^{-1}\right.$ $\mathrm{NaOH}$ hydrolysis $), 28.75 \mathrm{mg} \mathrm{kg}^{-1}$; available $\mathrm{P}(0.5 \mathrm{~mol}$ $\left.\mathrm{L}^{-1} \mathrm{NaHCO}_{3}\right), 30.46 \mathrm{mg} \mathrm{kg}^{-1}$; and available $\mathrm{K}\left(1 \mathrm{~mol} \mathrm{~L}^{-1}\right.$ neutral $\mathrm{NH}_{4} \mathrm{OAc}$ ), $153.68 \mathrm{mg} \mathrm{kg}^{-1}$.

The experiments started on March 1, 2012 and on March 3, 2013. Approximately $1.0 \mathrm{~kg}$ of air-dried soil was packed into pots $(10 \mathrm{~cm}$ diameter and $15 \mathrm{~cm}$ depth). Seed were sown in pots on March 5, 2012 and on March 7, 2013. Cucumber seedlings at the third-leaf stage were transplanted into the soil in the greenhouse, on April 13, 2012 and April 7, 2013, at 40,000 plants ha ${ }^{-1}$ density. Four rows, with six cucumber plants each, at $50 \mathrm{~cm}$ inter-row spacing, and $50 \mathrm{~cm}$ inter-plant spacing were transplanted in each plot over two years.

Four treatments were replicated in three fully randomized blocks $\left(6 \mathrm{~m}^{2}\right.$ per treatment), which are: control (CK, conventional practice without mulch); plastic film mulch (FM); combined mulch of plastic film with wheat straw $(\mathrm{CM}, 0.01 \mathrm{~mm}$ transparent polyethylene film, in planting row, and $3 \mathrm{~cm}$ length dry wheat straw, with $2,500 \mathrm{~kg} \mathrm{ha}^{-1}$ in operation row); and straw mulch (SM, $3 \mathrm{~cm}$ length dry wheat straw with $\left.5,000 \mathrm{~kg} \mathrm{ha}^{-1}\right)$. Fertilizers containing $\mathrm{N}\left(75 \mathrm{~kg} \mathrm{ha}^{-1}\right), \mathrm{P}$ $\left(75 \mathrm{~kg} \mathrm{ha}^{-1}\right)$ and $\mathrm{K}\left(75 \mathrm{~kg} \mathrm{ha}^{-1}\right)$ were applied to each plot on April 12 and June 13, 2012 and on April 6 and June 7, 2013. The treatments were established on April 30, 2012 and on April 25, 2013. Cucumbers were harvested on August 12, 2012 and on August 13, 2013.

During the growing seasons, May-August, in 2012 and 2013, Rs was measured with a soil respiration chamber LI-6400-09 (Li-Cor Inc., Lincoln, NE, USA) connected to a portable infrared gas analyzer IRGA LI-6400 (Li-Cor Inc., Lincoln, NE, USA) (Li et al., 2010). To minimize soil surface disturbances, the chambers were mounted on polyvinyl chloride (PVC) soil collars, sharpened at the bottom and inserted $3 \mathrm{~cm}$ into the soil. The PVC soil collars had $4.5 \mathrm{~cm}$ height and $11 \mathrm{~cm}$ diameter, and were installed 24 hours before the measurements on the mulching materials. When the measurements were performed, the treatment with the plastic film mulch (FM) was rapidly removed from the 
PVC collars, while wheat straw mulching remained in them. The collar on each experimental plot was placed near plants (about $5 \mathrm{~cm}$ from the plant), inter-plants (about $25 \mathrm{~cm}$ from the plants), and inter-rows (in the middle of 4 plants, approximately $39 \mathrm{~cm}$ from them). The seasonal measurements were performed between 9:00-11:00 h, on 12 and 31 May, 10 and 26 June, 5 and 20 July, in 2012, and on 23 May, 3, 14 and 25 June, 7, 19 and 27 July, in 2013. In addition, diurnal variations were measured every 2 hours, from 8:00 to 20:00 h, on 16 May, 10 June, and 5 July 2012, and on 23 May, 14 June, and 7 July 2013.

Air temperatures and air relative humidity were measured automatically by Hobo (Vaisala, Helsinki,
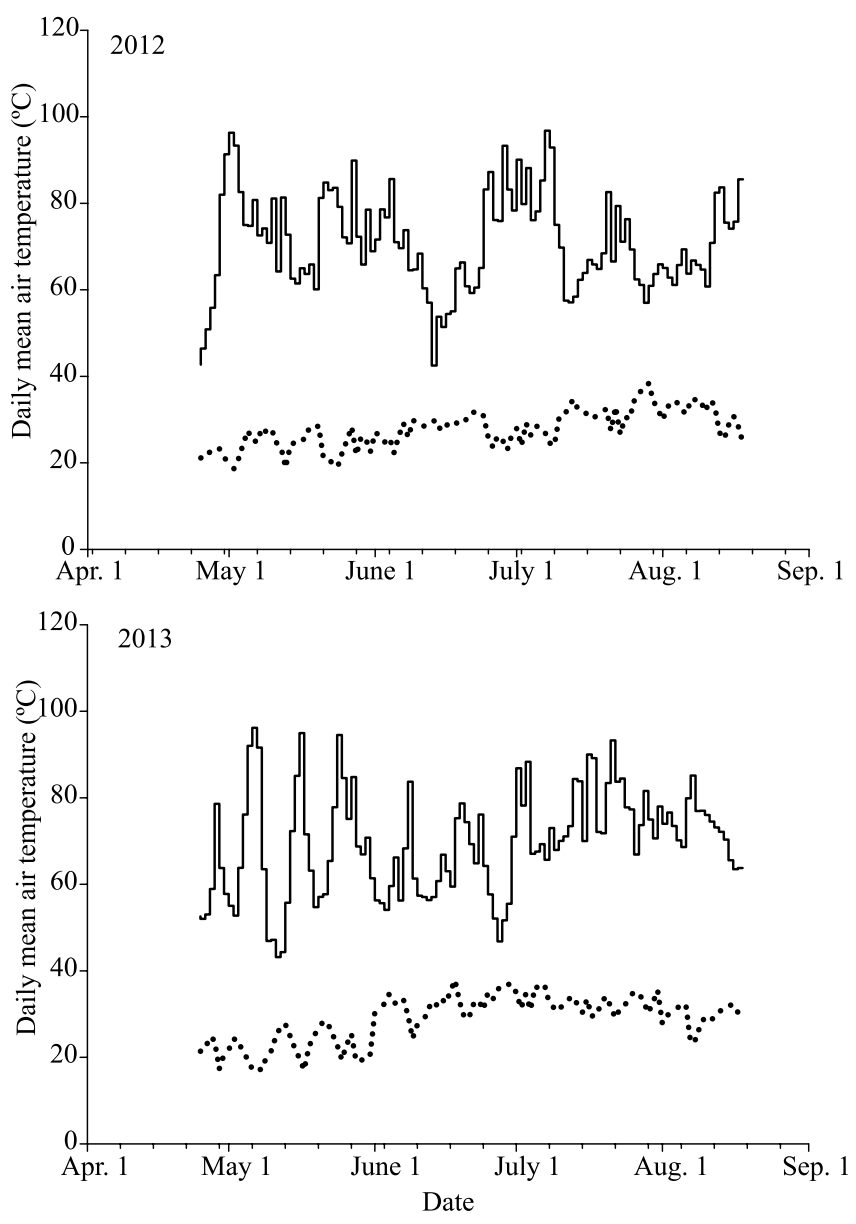

.... Daily mean air temperature — Daily mean air humidity

Figure 1. Daily mean air temperature and humidity in the greenhouse, in 2012 and 2013.
Finland), located in the middle of the plot area, at $1.5 \mathrm{~m}$ height. Soil temperature (Ts) in each plot was automatically recorded every hour, for the entire growing seasons, at 5, 10, 20, and $35 \mathrm{~cm}$ soil depths, in 2012 and 2013, using a portable LCD soil temperature meter TPJ-21 (Zhejiang Top Instrument Co., Ltd., China). Soil water content (SWC) - at 10, 20, 30, and $40 \mathrm{~cm}$ soil depths - was measured through TDR (time domain reflectometry) (Liang et al., 2011). Soil pH at $0-20 \mathrm{~cm}$ soil depth was measured in aqueous soil extracts in deionized water and soil (1:2.5 soil:water). Soil electrical conductivity (SEC) at $0-20 \mathrm{~cm}$ soil depth was measured in aqueous soil extracts in deionized water (1:5 soil:water), with a Nissan B-173 conductivity meter. Soil organic matter $(\mathrm{SOM})$ at $0-20 \mathrm{~cm}$ soil depth was determined with the oil bath $\mathrm{K}_{2} \mathrm{CrO}_{4}$ titration method after digestion.

To determine the root biomass, five samples of cucumber plants from each treatment were clipped to a ground level, and soil cores within $50 \mathrm{~cm}$ diameter were taken from $50 \mathrm{~cm}$ depth in the rows and between rows. Roots were washed many times, in order to remove the soil embedded in them and, then, all the samples were oven-dried at $105^{\circ} \mathrm{C}$ until a constant weight was obtained. Any nonderived material from the roots was removed before weighing the final product. Root vigor was measured by the triphenyl-tetrazolium chloride (TTC) method, which was clearly described by Zheng et al. (2016).

A one-way analysis of variation was used to test the differences in the Rs in response to mulching. Acorrelation analysis was used to examine the relationships between Rs and the controlling factors. A statistical analysis was performed using SPSS 17.0 for windows. Significance levels were set to $5 \%$ of probability.

\section{Results and Discussion}

In cucumber fields, Rs showed significant differences $(p<0.05)$ between the four mulching treatments, during the growing seasons in 2012 and 2013. And the average Rs of the two experimental years under CM, FM, SM were 6.0, 4.9, and $4.1 \mu \mathrm{mol} \mathrm{CO}_{2} \mathrm{~m}^{-2} \mathrm{~s}^{-1}$, which increased by 71,40 , and $17 \%$, in comparison with $\mathrm{CK}\left(3.5 \mu \mathrm{mol} \mathrm{CO} \mathrm{Cm}^{-2} \mathrm{~s}^{-1}\right)$ (Table 1). This is consistent with the research by Liu et al. (2010) and Zhang et al. (2015), who found higher Rs under mulching compared to nonmulched fields. Some studies (Hu et al., 2016; 
Zhao et al., 2016) have also reported that mulching has reduced Rs under plastic mulching, which differ from the results of the present study.

However, these researches were conducted in field conditions and very little information was available regarding the $\mathrm{Rs}$ in mulching agroecosystems in greenhouse in China. The differences in Rs, observed in our study in greenhouse, could be possibly due to the mulching materials added, in comparison to the conventional treatments, and also to the difference in amount and quality of these mulching types, which can have different effects on the biological properties and organic carbon mineralization of the soil, in accordance with other studies carried out on organic C mineralization (Mancinelli et al., 2013; Mu et al., 2014). Mulching practices in greenhouse also improved the microbial activity in the soil, thereby enhancing the release of nutrients, and increasing the soil nutrient levels. In addition, $\mathrm{CO}_{2}$ released from Rs in greenhouse was one of the carbon sources for photosynthesis, and mulching practices provided the carbon source for cucumber production (Bayer et al., 2015). Therefore, mulching was also recommended as a component within an integrated crop management

Table 1. Seasonal dynamic variation of soil respiration, under different mulching practices and cucumber (Cucumis sativus) cultivation, during the growing seasons in 2012 and $2013^{(1)}$.

\begin{tabular}{llccc}
\hline Date & \multicolumn{4}{c}{ Soil respiration $\left(\mu \mathrm{mol} \mathrm{CO}_{2} \mathrm{~m}^{-2} \mathrm{~s}^{-1}\right)$} \\
\cline { 2 - 4 } & $\mathrm{CK}$ & $\mathrm{FM}$ & $\mathrm{CM}$ & $\mathrm{SM}$ \\
\hline 12 May & $2.9 \mathrm{~d}$ & $3.5 \mathrm{~b}$ & $4.4 \mathrm{a}$ & $3.1 \mathrm{c}$ \\
31 May & $3.0 \mathrm{c}$ & $3.8 \mathrm{~b}$ & $5.1 \mathrm{a}$ & $3.6 \mathrm{~b}$ \\
10 June & $3.3 \mathrm{c}$ & $4.2 \mathrm{~b}$ & $5.8 \mathrm{a}$ & $4.4 \mathrm{~b}$ \\
26 June & $3.7 \mathrm{c}$ & $4.8 \mathrm{~b}$ & $6.3 \mathrm{a}$ & $4.6 \mathrm{~b}$ \\
5 July & $4.4 \mathrm{~b}$ & $5.9 \mathrm{~b}$ & $7.9 \mathrm{a}$ & $5.0 \mathrm{~b}$ \\
20 July & $3.0 \mathrm{c}$ & $4.4 \mathrm{~b}$ & $6.2 \mathrm{a}$ & $4.2 \mathrm{~b}$ \\
\hline & & 2013 growing & 5 season & \\
23 May & $3.2 \mathrm{c}$ & $4.0 \mathrm{~b}$ & $6.4 \mathrm{a}$ & $4.3 \mathrm{~b}$ \\
3 June & $4.5 \mathrm{c}$ & $7.3 \mathrm{~d}$ & $8.4 \mathrm{a}$ & $5.3 \mathrm{c}$ \\
14 June & $4.2 \mathrm{~b}$ & $7.4 \mathrm{a}$ & $7.9 \mathrm{a}$ & $4.2 \mathrm{~b}$ \\
25 June & $4.5 \mathrm{c}$ & $7.0 \mathrm{a}$ & $5.8 \mathrm{~b}$ & $5.1 \mathrm{~b}$ \\
7 July & $4.1 \mathrm{c}$ & $5.2 \mathrm{~b}$ & $6.2 \mathrm{a}$ & $4.2 \mathrm{c}$ \\
19 July & $2.3 \mathrm{~b}$ & $3.3 \mathrm{a}$ & $3.4 \mathrm{a}$ & $2.7 \mathrm{~b}$ \\
27 July & $2.8 \mathrm{~b}$ & $2.9 \mathrm{~b}$ & $3.9 \mathrm{a}$ & $2.7 \mathrm{~b}$ \\
\hline
\end{tabular}

${ }^{(1)}$ Means followed by different letters, in the lines, indicate significant differences among different mulching treatments, at $5 \%$ probability. CK, control without mulching; FM, plastic film mulch; CM, combined mulch of plastic film with wheat straw; and SM, wheat straw mulch. programme for crop production in greenhouse (Liang et al., 2011).

Appearing also as a seasonal characteristic in the greenhouse, Rs increased from May onwards, reached a maximum in late June, and then began to decrease in mid-July, which is consistent with the literature (Gaumont-Guay et al., 2006). Menichetti et al. (2015) reported that the changes of Rs in growing seasons were likely induced by soil temperature, which affected the respiratory enzymatic activity. The diurnal changes of Rs showed one-peak pattern curves, and also exhibited a similar diurnal undulate variation with a minimum value at 08:00 and 20:00 h, and a maximum value between 12:00 and 14:00 h, in all treatments in 2012 and 2013 (Figure 2). Chang et al. (2016) suggested that when $\mathrm{C}$ supply was scarce as plants prepared to resume photosynthesis in the morning, in greenhouse, shoots were a stronger sink for $\mathrm{C}$ supply than roots, and, that by early morning, soluble $\mathrm{C}$ in the soil substantially decreased, with both of those factors contributing to the reduction of Rs.

Over most of the observation days, Rs in cucumber culture in the different mulching treatments showed strong spatial variations. We found the same Rs pattern (near plant $>$ inter-plants $>$ inter-rows) in all the mulching treatments (Figure 3). Pangle \& Seiler (2002) observed annual mean $\mathrm{CO}_{2}$ efflux rates, near seedlings, that were on average $41 \%$ higher than the rates in plots away from the influence of seedling roots, in a 2-year-old loblolly pine plantation, which is consistent with our research. The probable reason is that the dicotyledonous cucumber has taproot systems with a main root and a lateral root development; these roots grow almost vertically throughout the soil. In addition to this, Nannipieri et al. (2008) found that the microbial communities in cucumber culture were affected by different root exudates.

In soil, Ts and SWC were considered to be two of the most important soil environmental factors controlling variations in Rs (Moyano et al., 2013), but their effects interact. In the present study, SWC and Ts measured under CK conditions were always significantly lower than those got across all mulching practices, and their sequence in the treatments was $\mathrm{CM}>\mathrm{SM}>\mathrm{FM}>\mathrm{CK}$ $(\mathrm{p}<0.05$, Figure 4$)$. The seasonal Rs and $\mathrm{SWC}$ relation was expected to follow an optimum curve (Byrne et al., 2005), and in the present study, SWC can be described together with the seasonal Rs response to Ts by a response plane (Figure 5). The Rs was more 


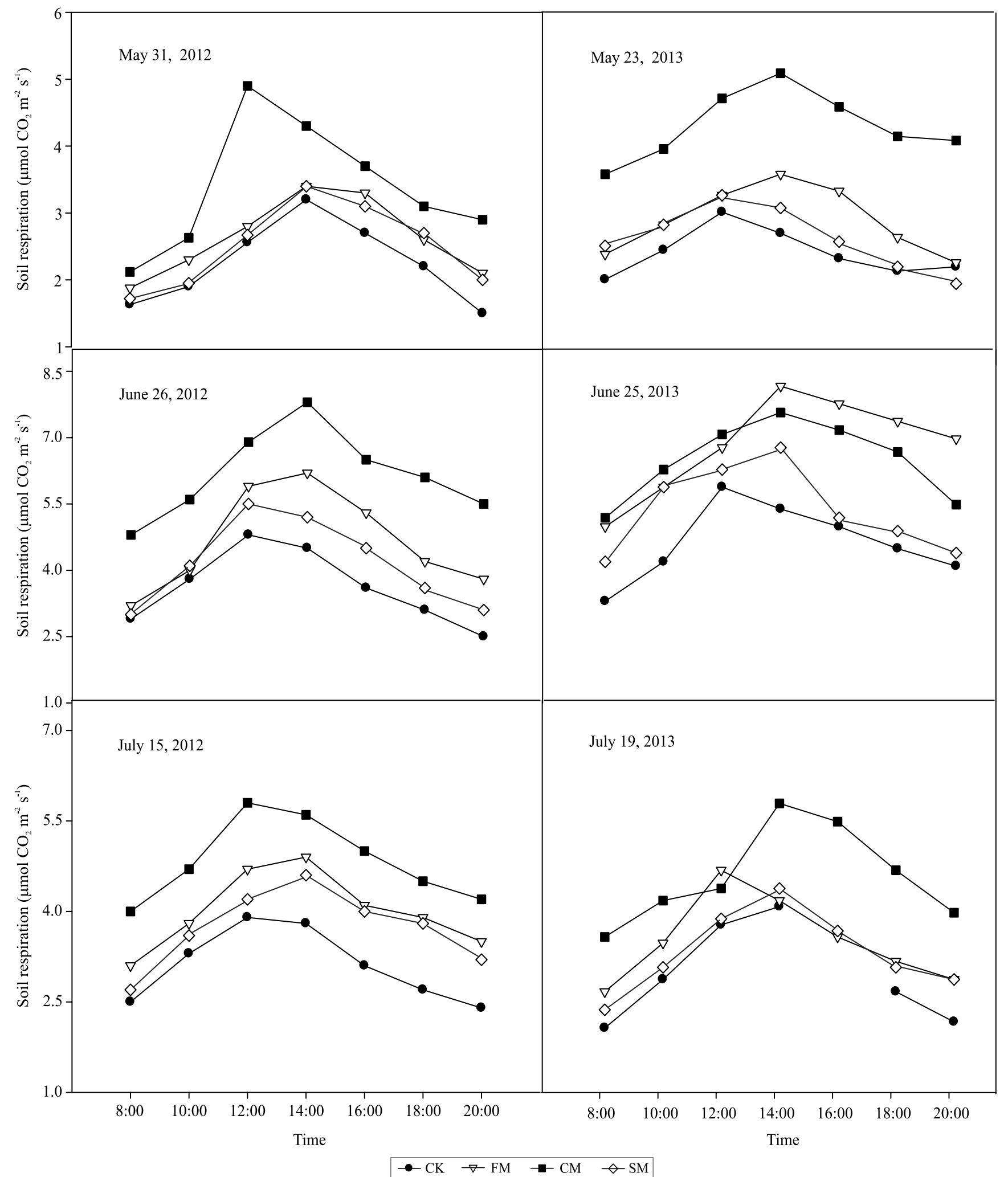

Figure. 2. Soil respiration diurnal variations from 08:00 to 20:00 of cucumber in response to different mulching treatments (mean \pm SD) on May 31, June 26, July 15, 2012 and May 23, June 25, and July 19, 2013. Treatments: CK, un-mulched control; FM, plastic film mulch; CM, combined mulch with plastic film and wheat straw; SM, wheat straw mulch. 


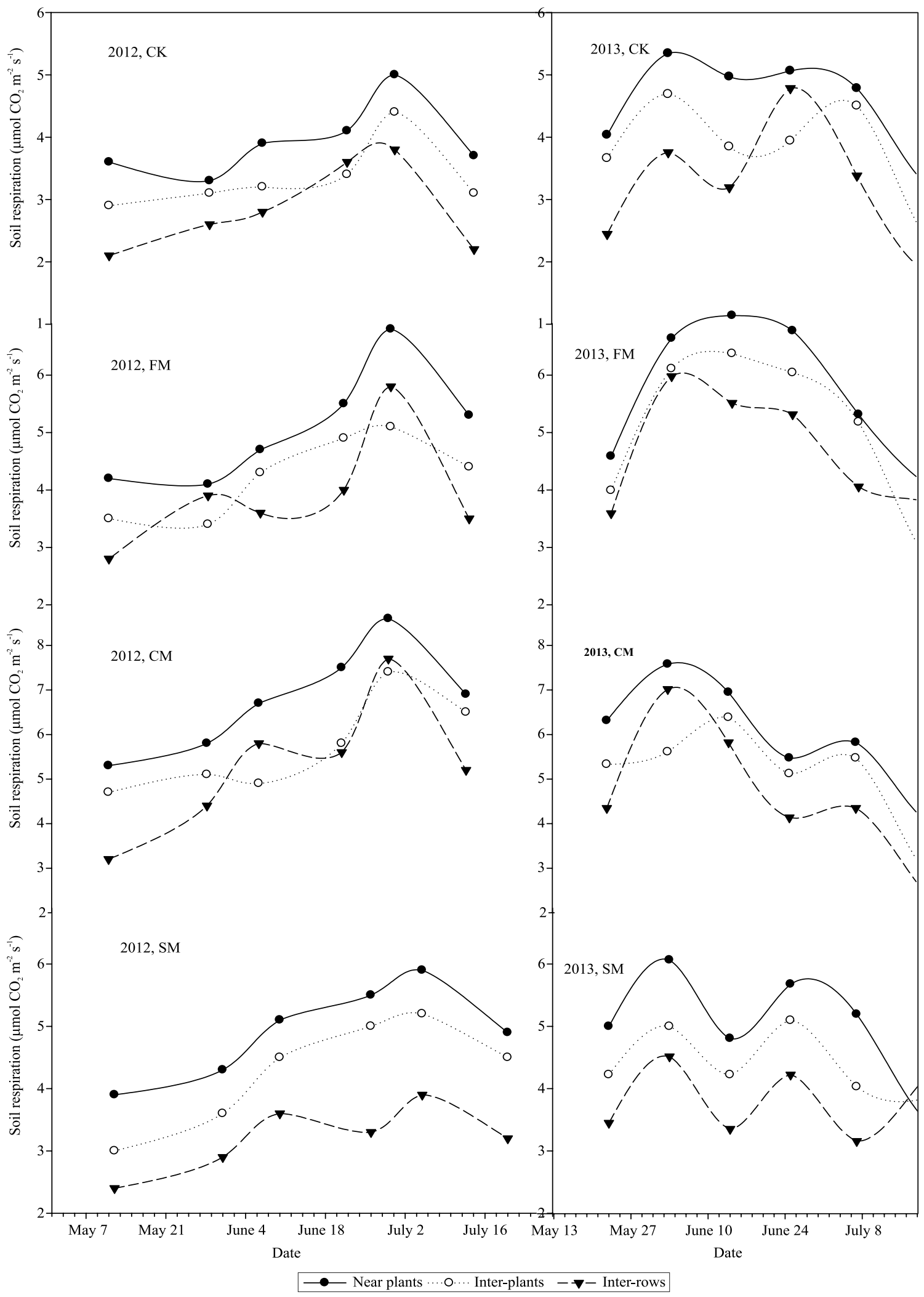

Figure 3. Soil respiration under mulching - near plants, inter-plants and inter-rows -, in a cucumber (Cucumis sativus) cultivation, during the growing seasons in 2012 and 2013. Treatments: CK, control without mulching; FM, plastic film mulch; CM, combined mulch of plastic film with wheat straw; SM, wheat straw mulch. 

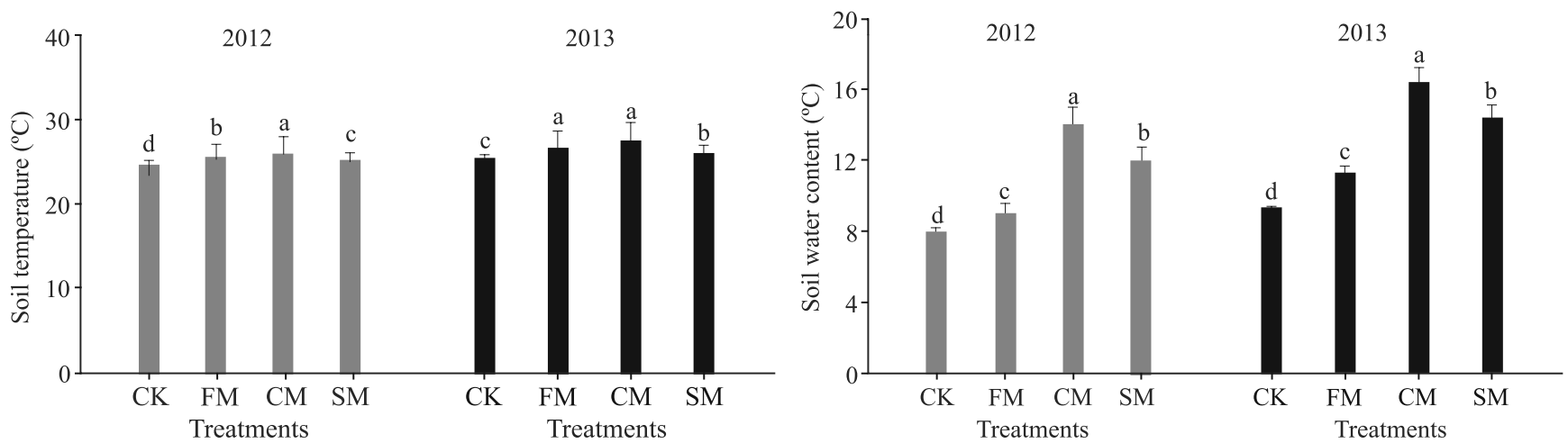

Figure 4. Soil temperature (0-20 cm soil depth) and soil water content (0-20 cm soil depth) of cucumber (Cucumis sativus), grown in a greenhouse under mulching practices during the fruit growth stage, in 2012 and 2013. Treatments: CK, control without mulching; FM, plastic film mulch; CM, combined mulch of plastic film with wheat straw; SM, wheat straw mulch. Lower case letters indicate significant differences among the different mulching treatments in 2012 and 2013.
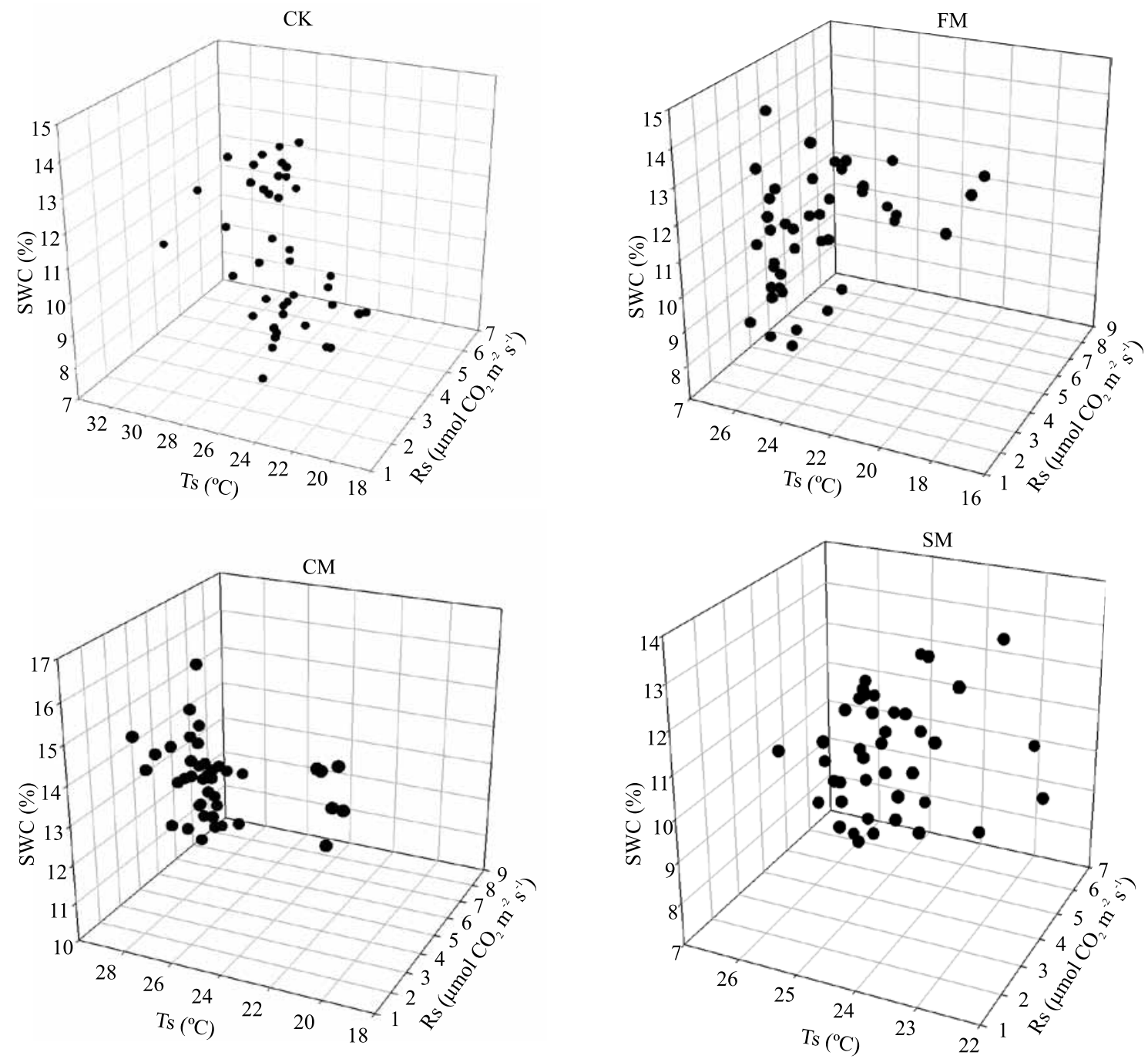

Figure 5. Dependence of soil respiration on soil temperature (at $5 \mathrm{~cm}$ soil depth) and soil water content $(0-10 \mathrm{~cm}$ soil depth), under mulching practices, in 2012 and 2013. Data points are the average of two-year seasonal Rs replications. Treatments: CK, control without mulching; FM, plastic film mulch; CM, combined mulch of plastic film with wheat straw; SM, wheat straw mulch. 
dependent on the SWC than on the Ts under CM and FM treatments, while RS for CK and SM was more influenced by Ts than by SWC. Daly et al. (2008) stated that SWC controlled Rs process and altered $\mathrm{CO}_{2}$ diffusivity by altering the soil effective porosity. In accordance with Jia et al. (2006), SWC had a stronger impact than temperature on Rs under soil saturation or water deficit. In contrast, for CK and SM, the Rs was more influenced by Ts than by SWC because the high soil temperature may have blocked substrate supply to microorganism respiration (Jiang et al., 2015). In this study, SOM and other soil factors were also measured, since various studies have found that Rs may depend on the concentration of soil organic carbon which supplies substrate to microorganism respiration, and on the photosynthetic activity which regulates soil microhabitat, as well as on the SWC and Ts (Luan et al., 2011). SOM, SEC, and soil $\mathrm{pH}$ were significantly higher under CM, FM, and SM than under the CK treatments (Table 2), in 2012 and 2013. Correlation analysis (Table 3 ) showed that SOM strongly influenced Rs and the correlation coefficients were $0.852,0.884$, 0.955 , and 0.811 - in 2012 -, and 0.812, 0.929, 0.872, and 0.899 - in 2013 -, under CK, FM, CM, and SM applications, respectively (Table 3 ). The reason for these results may be that global warming is considered to promote the decomposition of SOM and subsequent increase of Rs. SOM is decomposed by heterotrophic microorganisms, which are one of the key players

Table 2. Soil factors in response to mulching treatments, in a cucumber (Cucumis sativus) cultivation in greenhouse, in 2012 and $2013^{(1)}$.

\begin{tabular}{|c|c|c|c|c|}
\hline \multirow[t]{2}{*}{ Soil factor } & \multicolumn{4}{|c|}{ Treatment } \\
\hline & $\mathrm{CK}$ & FM & $\mathrm{CM}$ & SM \\
\hline & \multicolumn{4}{|c|}{2012 growing season } \\
\hline $\mathrm{pH}$ & $8.10 \mathrm{~b}$ & $8.12 \mathrm{a}$ & $8.13 \mathrm{a}$ & $8.12 \mathrm{a}$ \\
\hline SOM (\%) & $1.41 \mathrm{~d}$ & $1.63 b$ & $1.71 \mathrm{a}$ & $1.56 \mathrm{c}$ \\
\hline \multirow[t]{2}{*}{$\underline{\operatorname{SEC}\left(\mathrm{s} \mathrm{m}^{-1}\right)}$} & $0.06 \mathrm{~b}$ & $0.08 \mathrm{a}$ & $0.08 \mathrm{a}$ & $0.07 \mathrm{a}$ \\
\hline & \multicolumn{4}{|c|}{2013 growing season } \\
\hline $\mathrm{pH}$ & $8.11 b$ & $8.14 a$ & $8.14 \mathrm{a}$ & $8.13 \mathrm{a}$ \\
\hline SOM (\%) & $1.43 \mathrm{~d}$ & $1.65 \mathrm{c}$ & $1.81 \mathrm{a}$ & $1.73 b$ \\
\hline $\operatorname{SEC}\left(\mathrm{s} \mathrm{m}^{-1}\right)$ & $0.07 \mathrm{~b}$ & $0.08 \mathrm{a}$ & $0.09 \mathrm{a}$ & $0.08 \mathrm{a}$ \\
\hline
\end{tabular}

${ }^{(1)}$ Means followed by different letters, in the lines, indicate significant differences among different mulching treatments, at $5 \%$ probability. $\mathrm{CK}$, control without mulching; FM, plastic film mulch; CM, combined mulch of plastic film with wheat straw; SM, wheat straw mulch. SOM, soil organic matter; SEC, soil electrical conductivity. and components of the Rs for the global $\mathrm{C}$ cycle, due to the $\mathrm{CO}_{2}-\mathrm{C}$ fluxes they generate (Schindlbacher et al., 2011). Besides, root biomass increased under different mulching practices (Figure $6 \mathrm{~A}$ and $\mathrm{B}$ ), but the effect was not significant on CM and FM ( $p>0.05)$ treatments, in 2012. Meanwhile, there was a significant difference in root vigor for the mulching practices (Figure $6 \mathrm{C}$ and $\mathrm{D}, \mathrm{p}<0.05$ ), but not for $\mathrm{CK}$ and $\mathrm{SM}$, in 2013. Similarly, Rs exhibited a significantly positive linear relationship with soil root biomass $\left(\mathrm{R}^{2}=0.8183\right.$, $\mathrm{p}<0.05$, in 2012; $\mathrm{R}^{2}=0.8620, \mathrm{p}<0.05$, in 2013) and root vigor $\left(\mathrm{R}^{2}=0.8820, \mathrm{p}<0.05\right.$, in $2012 ; \mathrm{R}^{2}=0.9047$, $\mathrm{p}<0.05$, in 2013), which corroborates the results of Luo et al. (2015). It is likely that mulching may increase decomposable substrates to the soil, as rhizodeposition would be increased under mulching practices, due to the increased root growth, in comparison to CK. High soil-root biomass and its activity often facilitate high nutrient availability to cucumber, by the enhancement of both root biomass turnover and degradation of nonmicrobial organic materials. Thus, in the present study, the differences in root biomass and root activity under mulching applications are most likely caused by $\mathrm{C}$ increase, which is in turn caused by increased Rs (Rewald et al., 2015). Thus, understanding the biotic factors that control Rs, in greenhouse, is critical for estimating global carbon stock in agroecosystem .

Table 3. Relationships between Rs and environmental factors of a soil under mulching treatments, in a cucumber (Cucumis sativus) cultivation in greenhouse, in 2012 and 2013.

\begin{tabular}{|c|c|c|c|c|c|c|}
\hline \multirow{2}{*}{$\begin{array}{l}\text { Treat- } \\
\text { ment }\end{array}$} & \multicolumn{2}{|c|}{ SOM } & \multicolumn{2}{|c|}{$\mathrm{pH}$} & \multicolumn{2}{|c|}{ SEC } \\
\hline & $\begin{array}{c}\text { Pearson } \\
\text { correlation }\end{array}$ & $\begin{array}{l}\text { p-value }{ }^{(1)} \\
\text { (2-tailed) } \\
\end{array}$ & $\begin{array}{c}\text { Pearson } \\
\text { correlation }\end{array}$ & $\begin{array}{l}\text { p-value }{ }^{(1)} \\
\text { (2-tailed) }\end{array}$ & $\begin{array}{c}\text { Pearson } \\
\text { correlation }\end{array}$ & $\begin{array}{l}\text { p-value }{ }^{(1)} \\
\text { (2-tailed) }^{2}\end{array}$ \\
\hline & \multicolumn{6}{|c|}{2012 growing season } \\
\hline CK & $0.852 *$ & 0.031 & 0.410 & 0.420 & 0.164 & 0.756 \\
\hline FM & $0.884 *$ & 0.019 & 0.260 & 0.618 & $0.970 * *$ & 0.001 \\
\hline $\mathrm{CM}$ & $0.955^{* *}$ & 0.003 & -0.077 & 0.885 & $0.846^{*}$ & 0.034 \\
\hline \multirow[t]{2}{*}{ SM } & $0.811 * *$ & 0.050 & 0.397 & 0.436 & 0.637 & 0.174 \\
\hline & \multicolumn{6}{|c|}{2013 growing season } \\
\hline $\mathrm{CK}$ & $0.812 *$ & 0.026 & 0.006 & 0.991 & 0.694 & 0.084 \\
\hline FM & $0.929 * *$ & 0.002 & 0.351 & 0.44 & 0.670 & 0.100 \\
\hline $\mathrm{CM}$ & $0.872 *$ & 0.011 & $0.706^{*}$ & 0.076 & $0.909^{* *}$ & 0.005 \\
\hline SM & $0.899 *$ & 0.006 & 0.411 & 0.36 & 0.746 & 0.054 \\
\hline
\end{tabular}

${ }^{(1)}$ Statistical significance. $*$ and $* *$ Significant at 5 and $1 \%$ probability, respectively. CK, control without mulching; FM, plastic film mulch; CM, combined mulch of plastic film with wheat straw; SM, wheat straw mulch; SOM, soil organic matter; SEC, soil electrical conductivity. 

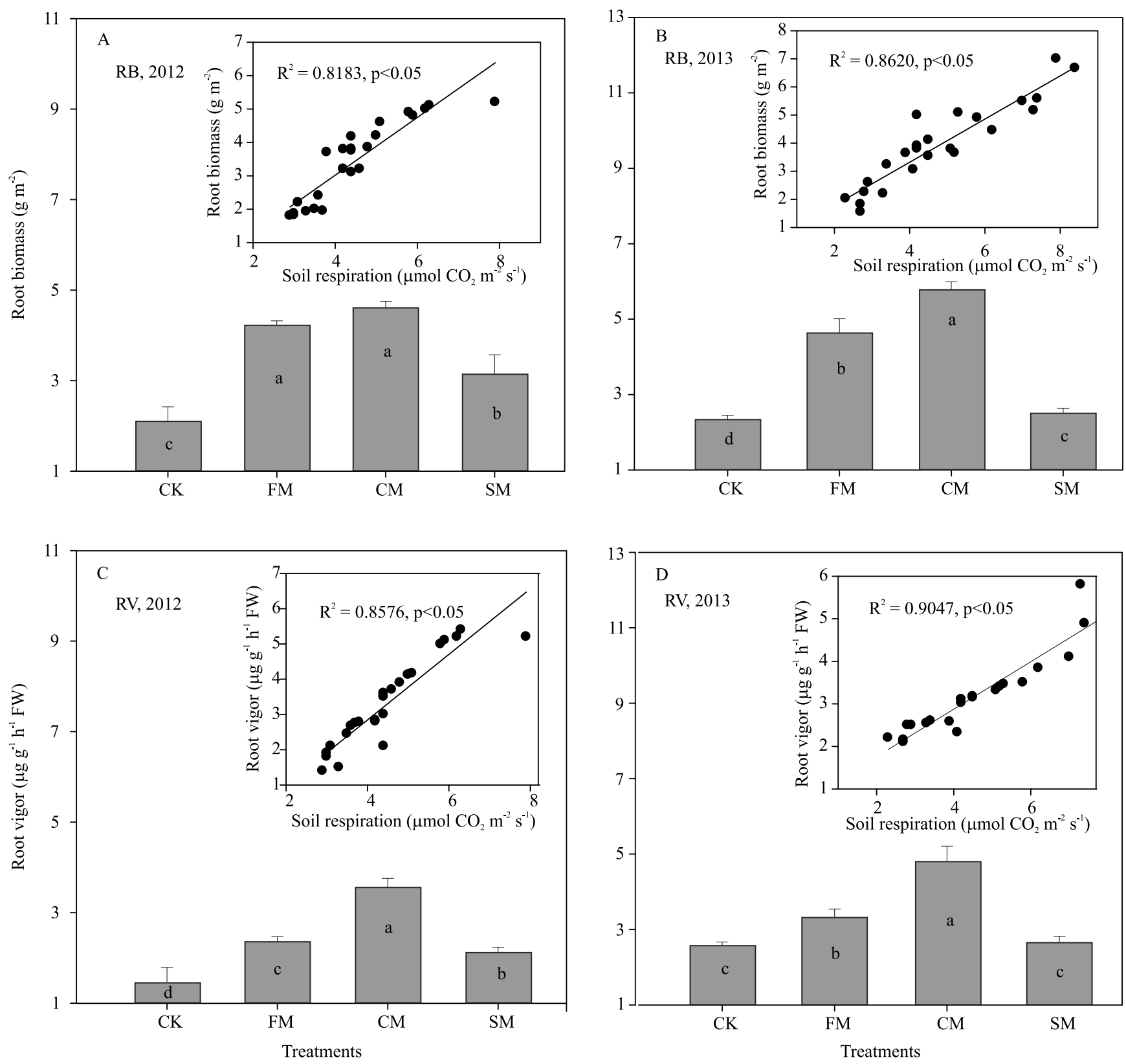

Figure 6. Relationships between soil respiration with root biomass and root vigor, as well as comparison of mean root biomass and root vigor, in a cucumber (Cucumis sativus) cultivation subjected to different mulching treatments, in 2013 and 2012.

\section{Conclusions}

1. Soil respiration exhibits a one-peak pattern curve in diurnal undulate; it decreases as the distance from cucumber plant increases, in the greenhouse, and it shows strong temporal and spatial variations under mulching applications, which would be useful for calculating carbon emissions more accurately in greenhouse.
2. Soil respiration under mulching is significantly higher than under the control treatment without mulching, for cucumber cultivation in greenhouse, and this would be recommended as a component within an integrated crop management programme for cucumber production and carbon sequestration in greenhouse. 


\section{Acknowledgments}

To China Postdoctoral Science Foundation, for grant (No. 2015M580807); to Fundamental Research Funds for the Central Universities (project No. 15SZYB22), and to Key Research Centers for Humanities and Social Sciences of Ministry of Education (project Nos. 11JJD790012 and 11YJA790027), for financial support.

\section{References}

AGELE, S.O.; OLAORE, J.B.; AKINBODE, F.A. Effect of some mulch materials on soil physical properties, growth and yield of sunflower (Helianthus Annuus, L.). Advances in Environmental Biology, v.4, p.368-375, 2010.

BAYER, A.D.; PUGH, T.A.M.; KRAUSE, A.; ARNETH, A. Historical and future quantification of terrestrial carbon sequestration from a greenhouse-gas-value perspective. Global Environmental Change, v.32, p.153-164, 2015. DOI: 10.1016/j. gloenvcha.2015.03.004.

BYRNE, K.A.; KIELY, G.; LEAHY, P. $\mathrm{CO}_{2}$ fluxes in adjacent new and permanent temperature grasslands. Agricultural and Forest Meteorology, v.135, p.82-92, 2005. DOI: 10.1016/j. agrformet.2005.10.005.

CAMPIGLIA, E.; MANCINELLI, R.; RADICETTI, E. Influence of no-tillage and organic mulching on tomato (Solanum lycopersicum L.) production and nitrogen use in the Mediterranean environment of central Italy. Scientia Horticulturae, v. 130, p.588-598, 2011. DOI: 10.1016/j.scienta.2011.08.012.

CHANG, S.X; SHI, Z.; THOMAS, B.R. Soil respiration and its temperature sensitivity in agricultural and afforested poplar plantation systems in northern Alberta. Biology and Fertility of Soils, v.2, p.1-13, 2016. DOI: 10.1007/s00374-016-1104-x.

DALY, E.; OISHI, A.C.; PORPORATO, A.; KATUL, G.G. A stochastic model for daily subsurface $\mathrm{CO}_{2}$ concentration and related soil respiration. Advances in Water Resources, v.31, p.987-994, 2008. DOI: 10.1016/j.advwatres.2008.04.001.

DOSSOU-YOVO, E.R.; BRÜGGEMANN, N.; JESSE, N.; HUAT, J.; AGO, E.E.; AGBOSSOU, E.K. Reducing soil CO2 emission and improving upland rice yield with no-tillage, straw mulch and nitrogen fertilization in northern Benin. Soil and Tillage Research, v.156, p.44-53, 2016. DOI: 10.1016/j.still.2015.10.001.

GAUMONT-GUAY, D.; BLACK, T.A.; GRIFFIS, T.J.; BARR, A.G.; JASSAL, R.S.; NESIC, Z. Interpreting the dependence of soil respiration on soil temperature and water content in a boreal aspen stand. Agricultural and Forest Meteorology, v.140, p.220-235, 2006. DOI: 10.1016/j.agrformet.2006.08.003.

GUAN, Q.; WANG, J.; SONG, S.; LIU, W. Effects of different mulching measures on winter wheat field soil respiration in Loess Plateau dry land region. Chinese Journal of Applied Ecology, v.22, p.1471-1476, 2011.

HU, F.; GAN, Y.; CUI, H.; ZHAO, C.; FENG, F.; YIN, W.; CHAI, $\mathrm{Q}$. Intercropping maize and wheat with conservation agriculture principles improves water harvesting and reduces carbon emissions in dry areas. European Journal of Agronomy, v.74, p.9-17, 2016. DOI: 10.1016/j.eja.2015.11.019.

JIA, B.; ZHOU, G.; WANG, F.; WANG, Y.H.; YUAN, W.; ZHOU, L. Partitioning root and microbial contributions to soil respiration in Leymus chinensis populations. Soil Biology and Biochemistry, v.38, p.653-660, 2006. DOI: 10.1016/j.soilbio.2005.06.027.

JIANG, J.; GUO, S.; ZHANG, Y.; LIU, Q.; WANG, R.; WANG, Z.; LI, N.; LI, R. Changes in temperature sensitivity of soil respiration in the phases of a three-year crop rotation system. Soil and Tillage Research, v.150, p.139-146, 2015. DOI: 10.1016/j. still.2015.02.002.

LI, X.; FU, H.; GUO, D.; LI, X.; WAN, C. Partitioning soil respiration and assessing the carbon balance in a Setaria italica (L.) Beauv. Cropland on the Loess plateau, Northern China. Soil Biology and Biochemistry, v.42, p.337-346, 2010. DOI: 10.1016/j. soilbio.2009.11.013

LIANG, Y.-L.; WU, X.; ZHU, J.-J.; ZHOU, M.-J.; PENG, Q. Response of hot pepper (Capsicum annuum L.) to mulching practices under planted greenhouse condition. Agricultural Water Management, v.99, p.111-120, 2011. DOI: 10.1016/j. agwat.2011.07.010.

LIU, Y.; LI, S.Q.; YANG, S.J.; HU, W.; CHEN, X.P. Diurnal and seasonal soil $\mathrm{CO}_{2}$ flux patterns in spring maize fields on the Loess Plateau, China. Acta Agriculturae Scandinavica Section B - Soil and Plant Science, v.60, p.245-255, 2010. DOI: 10.1080/09064710902878121.

LUAN, J.; LIU, S.; ZHU, X.; WANG, J. Soil carbon stocks and fluxes in a warm-temperate oak chronosequence in China. Plant and Soil, v.347, p.243-253, 2011. DOI: 10.1007/s11104-011-0842-7.

LUO, S.; ZHU, L.; LIU, J.; BU, L.; YUE, S.; SHEN, Y.; LI, S. Sensitivity of soil organic carbon stocks and fractions to soil surface mulching in semiarid farmland. European Journal of Soil Biology, v.67, p.35-42, 2015. DOI: 10.1016/j.ejsobi.2015.01.004.

MANCINELLI, R.; MARINARI, S.; DI FELICE, V.; SAVIN, M.C.; CAMPIGLIA, E. Soil property, $\mathrm{CO}_{2}$ emission and aridity index as agroecological indicators to assess the mineralization of cover crop green manure in a Mediterranean environment. Ecological Indicators, v.34, p.31-40, 2013. DOI: 10.1016/j. ecolind.2013.04.011.

MENICHETTI, L.; REYES ORTIGOZA, A.L.; GARCÍA, N.; GIAGNONI, L.; NANNIPIERI, P.; RENELLA, G. Thermal sensitivity of enzyme activity in tropical soils assessed by the $\mathrm{Q}_{10}$ and equilibrium model. Biology and Fertility of Soils, v.51, p.299-310, 2015. DOI: 10.1007/s00374-014-0976-x.

MOYANO, F.E.; MANZONI, S.; CHENU, C. Response of soil heterotrophic respiration to moisture availability: an exploration of processes and model. Soil Biology and Biochemistry, v.59, p.72-85, 2013. DOI: 10.1016/j.soilbio.2013.01.002.

MU, L.; LIANG, Y.; ZHANG, C.; WANG, K.; SHI, G. Soil respiration of hot pepper (Capsicum annuum L.) under different mulching practices in a greenhouse, including controlling factors in China. Acta Agriculturae Scandinavica Section B - Soil and Plant Science, v.64, p.85-95, 2014. 
NANNIPIERI, P.; ASCHER, J.; CECCHERINI, M.T.; LANDI, L.; PIETRA- MELLARA, G.; RENELLA, G.; VALORI, F. Effects of root exudates in microbial diversity and activity in rhizosphere soils. In: NAUTIYAL, C.S.; DION, P. (Ed.). Molecular Mechanisms of Plant and Microbe Coexistence. Berlin: Springer, 2008. p.339-365. (Soil Biology, v.15).

PANGLE, R.E.; SEILER, J. Influence of seedling roots, environmental factors and soil characteristics on soil $\mathrm{CO}_{2}$ efflux rates in a 2-year-old loblolly pine (Pinus taeda L.) plantation in the Virginia Piedmont. Environmental Pollution, v.116, p.S85-96, 2002. Supplement 1. DOI : 10.1016/S0269-7491(01)00261-5.

QIU, R.; SONG, J.; DU, T.; KANG, S.; TONG, L.; CHEN, R.; WU, L. Response of evapotranspiration and yield to planting density of solar greenhouse grown tomato in Northwest China. Agricultural Water Management, v.130, p.44-51, 2013. DOI: 10.1016/j.agwat.2013.08.013.

RAHIL, M.H.; QANADILLO, A. Effects of different irrigation regimes on yield and water use efficiency of cucumber crop. Agricultural Water Management, v.148, p.10-15, 2015. DOI: 10.1016/j.agwat.2014.09.005.

REWALD, B.; HOLZER, L.; GÖRANSSON, H. Arbuscular mycorrhiza inoculum reduces root respiration and improves biomass accumulation of salt-stressed Ulmus glabra seedlings.
Urban Forestry and Urban Greening, v.14, p.432-437, 2015. DOI: 10.1016/j.ufug.2015.04.011.

SCHINDLBACHER,A.; RODLER,A.; KUFFNER, M.; KITZLER, B.; SESSITSCH, A.; ZECHMEISTERBOLTENSTERN, S. Experimental warming effects on the microbial community of a temperate mountain forest soil. Soil Biology and Biochemistry, v.43, p.1417-1425, 2011. DOI: 10.1016/j.soilbio.2011.03.005.

SCHLESINGER, W.H.; ANDREWS, J.A. Soil respiration and the global carbon cycle. Biogeochemistry, v.48, p.7-20, 2000. DOI: 10.1023/A:1006247623877.

ZHANG, F.; LI, M.; QI, J.; LI, F.; SUN, G. Plastic film mulching increases soil respiration in ridge-furrow maize management. Arid Land Research and Management, v.29, p.432-453, 2015. DOI: 10.1080/15324982.2015.1018456.

ZHAO, X.M.; HE, L.; ZHANG, Z.D.; WANG, H.B.; ZHAO, L.P. Simulation of accumulation and mineralization $\left(\mathrm{CO}_{2}\right.$ release $)$ of organic carbon in chernozem under different straw return ways after corn harvesting. Soil and Tillage Research, v.156, p.148-154, 2016. DOI: 10.1016/j.still.2015.11.001.

ZHENG, S.L.; CHENG, H.; LI, P.H.; YUAN, J.C. Root vigor and kinetic characteristics and nitrogen use efficiencies of different potato (Solanum tuberosum L.) cultivars. Journal of Agricultural Science Technology, v.18, p.399-410, 2016.

Received on November 19, 2015 and accepted on April 12, 2016 